\title{
SEPARATION OF COBALT FROM THE NICKEL-RICH SOLUTION FROM HPAL PROCESS BY SYNERGISM USING ORGANIC EXTRACTS CYANEX 272 AND IONQUEST 290
}

\author{
Gabriela Ferrante Rijo de Oliveira' \\ Amilton Barbosa Botelho Junior ' \\ Jorge Alberto Soares Tenório '
}

\begin{abstract}
The recovery of nickel from laterite ores has been increasing during the years. From the limonite layers of laterite ores, HPAL process is used to recover nickel and also cobalt. After the leaching step using sulfuric acid, a separation step is required. lon exchange technique is commonly used, mainly solvent extraction. Cyanex 272 is usually used as an organic extract to separate cobalt from nickel-rich solution. Despite that, the use of more than one organic extract can increase the metals separation and it is not explored. The goal of this work was to study the synergism of Cyanex 272 and lonquest 290 to separate cobalt from nickel-rich solution. Experiments were performed at $\mathrm{pH} 5.2$ and $65^{\circ} \mathrm{C}$. Results showed that cobalt separation was maximum using $80 \%$ of lonquest 290 and $20 \%$ of Cyanex 272 (99.3\%). Nickel losses were minimum using $60 \%$ of lonquest $290-4.6 \%$. Manganese, copper, zinc and calcium were all extracted in all experiments.
\end{abstract}

Keywords: Solvent extraction; Nickel laterite; Hydrometallurgy; Synergism.

\section{INTRODUCTION}

Nickel laterite ores represent $70 \%$ of nickel resources and $40 \%$ of nickel production. It occurs due to the difficult of processing nickel laterites compared with sulfides. Nevertheless, nickel production from laterite ores has been increasing due to the nickel consumption increase, and also because sulfide ores are decreasing $[1,2]$.

Among the metals that can be found with nickel is cobalt, in which it has great economic importance [3]. Hydrometallurgical process is commonly used to recover those metals from laterite ores. High-pressure acid leaching process (HPAL) is used mainly on limonite layers [4]. The process is composed of a leaching step (under pressure) using sulfuric acid, followed by a purification and separation step [5].

Precipitation can be used to purify the solution. Jiménez Correa et al. [6] used sodium hydroxide to remove iron from solution of nickel laterite. All iron removal was possible increasing the $\mathrm{pH}$ until 3.0. However, there were co-precipitation of copper and cobalt during the process. Moreover, precipitation can be used to obtain the desire metal. Anes et al. [7] studied the selective copper recovery from nickel laterite leach solution using sodium dithionite. Results showed that reducing the redox potential of the solution until $240 \mathrm{mV}$, copper precipitates as sulphide $[7,8]$. There are two mainly separation technique used on hydrometallurgical process: solvent extraction [9-15] and ion exchange resins $[3,16-22]$.
Anes et al. [7] studied two chelating ion exchange resins for nickel, cobalt and copper recovery from nickel laterite leach solution in batch experiments. A pre-reducing process using sodium sulfide was used to convert ferric iron to ferrous iron. Copper recovery was higher at pH 2.0 using Lewatit TP 207, with iminodiacetate functional group. For nickel and cobalt recovery, Lewatit TP 220, with bis-picolylamine functional group, was studied and metals adsorption were higher at $\mathrm{pH} 3.5$ and at $\mathrm{pH} 2.0$, respectively [22].

Aliprandini [23] studied the separation of metals by solvent extraction using Cyanex 272 and Acorga M5640. Due to the high concentration of iron in solution, losses of cobalt occurs on iron removal using Cyanex 272. However, by this process, it was possible to obtain a nickel-rich solution with no losses of it [23].

The advantage of solvent extraction is the high efficiency to separate metals, mainly cobalt from nickel $[13,24]$. All cobalt from nickel laterite leach solution can be separated using Cyanex 272 in kerosene, where it is effective at $\mathrm{pH} 5.2$ and $65^{\circ} \mathrm{C}$ with no losses of nickel [25]. Figure I shows the structure of bis(2,4,4-trimethylpentyl)phosphinic acid (a), the active component of Cyanex 272. The effect of $\mathrm{pH}(\mathrm{b})$ is presented, and it is possible seen that cobalt extraction is higher at $\mathrm{pH}$ above 5 , while nickel extraction starts at $\mathrm{pH}$ above 6 [26].

'Departamento de Engenharia Química, Escola Politécnica, Universidade de São Paulo - USP, São Paulo, SP, Brasil. E-mail: amilton.junior@usp.br 
The use of more than I organic extract is called synergism, which is enable to increase the rate of extraction. This topic is poorly explored on literature, despite its importance for the mining industries which uses solvent extraction on extractive processes [27]. Guimarães et al. [14] studied the purification of nickel laterite leach solution using Cyanex 272 and Versatic 10. The Cyanex 272 was used to remove cobalt, zinc, copper and manganese from the solution. Then, nickel-rich solution was purified using Cyanex 272 and Versatic 10 (synergism), where $80 \%$ of nickel was purified [28].

The goal of this work was to study synergism for cobalt separation from nickel-rich solution from high-pressure leaching process of nickel laterite ore. The organic extracts studied were Cyanex 272 and lonquest 290 diluted in kerosene at $20 \%$. lonquest 290 has the same functional group of Cyanex 272 (Figure I). The effect of synergism was evaluated. The aqueous/organic phase ratio was $2 / 1$. The concentration of lonquest 290 was studied from $0 \%$ (100\% Cyanex 272) to 100\%. The distribution coefficient and the separation factor were also evaluated. Experiments were performed at $65^{\circ} \mathrm{C}$ and $\mathrm{pH}$ 5.2. After separation of the phases, the aqueous phase was analyzed in ICP-OES.

\section{MATERIALS AND METHODS}

\section{I Materials}

A synthetic solution was prepared to simulate the real laterite nickel leachate. Sulphate salts of each metals were dissolved in deionized water. Table I presents the metals concentration on synthetic solution. Nickel is the main element $-88 \mathrm{~g} / \mathrm{L}-$ followed by magnesium and cobalt,
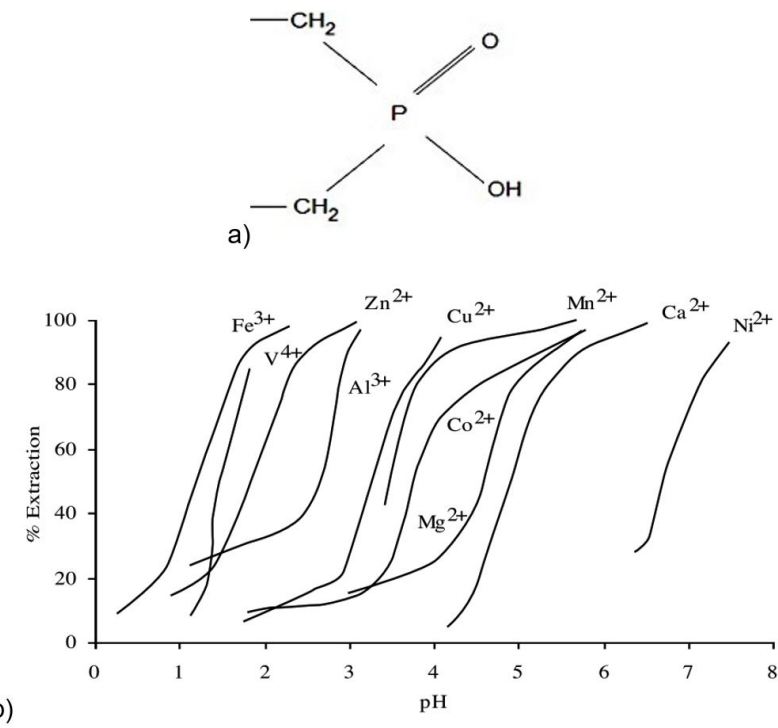

Figure I. Chemical structure of bis(2,4,4-trimethylpentyl)phosphinic acid (a) and the effect of pH on metals extraction (b). (Adapt. from [26]).
$3.03 \mathrm{~g} / \mathrm{L}$ and $2.95 \mathrm{~g} / \mathrm{L}$, respectively. The contaminants present in solution were manganese, magnesium, copper, calcium and zinc.

Organic extracts studied were Cyanex 272 and lonquest 290. No treatment was done on these solvents before use. Both solvents were diluted in kerosene in ratio $20 \%$ organic extract / $80 \%$ kerosene. Table 2 presents the percentage of organic extracts used for the experiments. Experiment I indicated that just lonquest 290 was used on the experiment. Experiment 2 indicated that $80 \%$ of lonquest 290 and $20 \%$ of Cyanex 272 of organic extract was used, that is, the organic phase was composed of $16 \%$ lonquest, $4 \%$ of Cyanex 272 and $80 \%$ of kerosene.

\subsection{Experiments}

Experiments were performed at $\mathrm{pH} 5.2$ and $65^{\circ} \mathrm{C}$. Aqueous/organic ratio was $2 / 1$, which were mixed using magnetic stirrer with heating. The mixed solution was stirred during $20 \mathrm{~min}$ and the $\mathrm{pH}$ was controlled using sulphuric acid. A separation funnel was used to separate aqueous from organic phase. The concentration of metals in aqueous phase was analyzed in Inductively Coupled Plasma Optical Emission Spectrometry (ICP-OES).

\section{RESULTS AND DISCUSSION}

Figure 2 presents the percentage of metals extracted from synthetic solution from $0 \%$ of lonquest 290 (100\% of Cyanex 272) to $100 \%$ of lonquest 290 . Results shows that cobalt extraction increased from $94.0 \%$, using $100 \%$ of Cyanex 272, to $99.0 \%$, using $100 \%$ of lonquest 290 . All manganese, copper, zinc and calcium were extracted.

Table I. Concentration of metals in synthetic solution of nickel laterite leachate $(\mathrm{g} / \mathrm{L})$

\begin{tabular}{cc}
\hline Metal & Concentration $(\mathrm{g} / \mathrm{L})$ \\
\hline $\mathrm{Ni}$ & 88 \\
$\mathrm{Co}$ & 2.95 \\
$\mathrm{Mn}$ & 0.55 \\
$\mathrm{Mg}$ & 3.03 \\
$\mathrm{Cu}$ & 0.25 \\
$\mathrm{Zn}$ & 0.07 \\
$\mathrm{Ca}$ & 0.5 \\
\hline
\end{tabular}

Table 2. Percentage of organic extracts used for cobalt separation

\begin{tabular}{ccc}
\hline Experiment & \%lonquest 290 & \%Cyanex 272 \\
\hline 1 & $100 \%$ & $0 \%$ \\
2 & $80 \%$ & $20 \%$ \\
3 & $60 \%$ & $40 \%$ \\
4 & $40 \%$ & $60 \%$ \\
5 & $20 \%$ & $80 \%$ \\
6 & $0 \%$ & $100 \%$ \\
\hline
\end{tabular}




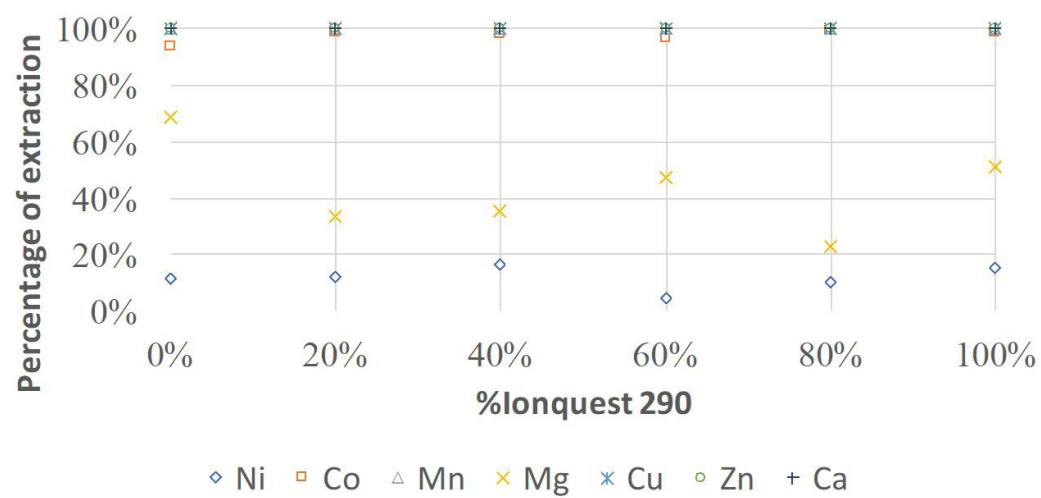

Figure 2. Percentage of metals extracted from aqueous phase using lonquest 290 and Cyanex 272

The cobalt separation was maximum using $80 \%$ of lonquest 290-99.3\%.

Nickel losses decreased from 14.9\% (Experiment I) to II.2\% (Experiment 6). In the meantime, the magnesium extraction varied in the synergism experiments, which indicated that the synergism between both organic solvents affect the magnesium extraction. Magnesium extraction was $50.8 \%$ and $68.9 \%$ using $100 \%$ of lonquest 290 and $100 \%$ Cyanex 272, respectively.

The distribution coefficient was calculated by dividing metal concentration in aqueous phase by metal concentration in organic phase. Results for cobalt (a), nickel and magnesium (b) are showed in Figure 3. By the distribution coefficient, it is possible to evaluate the efficiency of the metal extraction. The higher value of the coefficient, the greater the tendency to extract the metal $[23,29,30]$.

Cobalt distribution coefficient was 206.3, using $100 \%$ of lonquest 290, and 39.6, using 100\% of Cyanex 272. The distribution coefficient was 284.5 for the cobalt using $80 \%$ of lonquest 290 , where $99.3 \%$ of this metal was extracted, which indicated the highest separation. The cobalt distribution coefficient reached the lowest value for $100 \%$ of Cyanex 272 ( $94 \%$ of extraction), which indicated that the use of lonquest 290 is better for cobalt separation.

Nickel distribution coefficient varied from 0.5 to 0.6 using $100 \%$ of lonquest 290 and $100 \%$ of Cyanex 272 , respectively. Magnesium distribution coefficient varied from 2.2 to 1.4 using $100 \%$ of lonquest 290 and $100 \%$ of Cyanex 272, respectively. Magnesium distribution coefficient was 6.9 using $80 \%$ of lonquest 290 .

The separation factor was calculated for the ratios cobalt/nickel (a), cobalt/magnesium and magnesium/nickel (b), as showed in Figure 4. The separation factor is used to measure the viability of the separation of two metals. If the separation factor is higher than I, it means that the extraction process occurs, but if it is less than I, the separation does not occur. It also indicates the ease of the process, because the higher the calculated value of the factor, the smaller the number of stages necessary for the separation [3I].

The separation factor is calculated by the distribution coefficient ratio of two metals. Cobalt/nickel ratio was

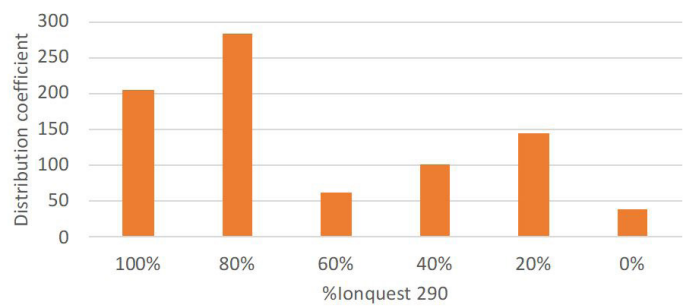

a)

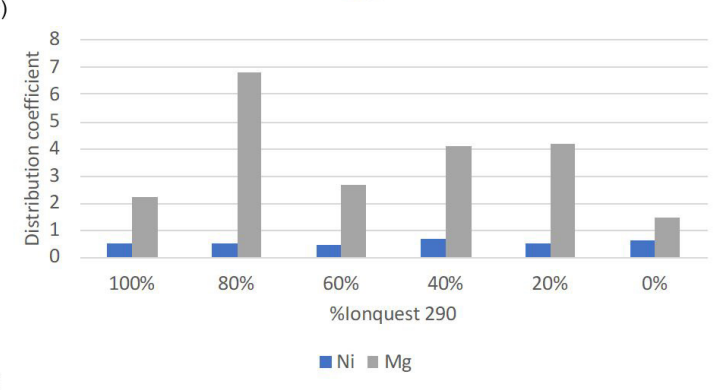

b)

Figure 3. Distribution coefficient for cobalt (a), nickel and magnesium (b) of the experiments performed.

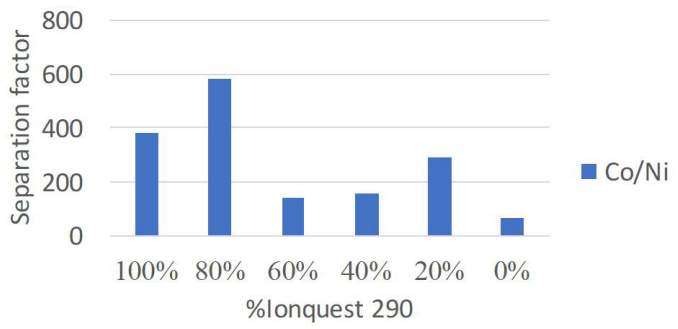

a)

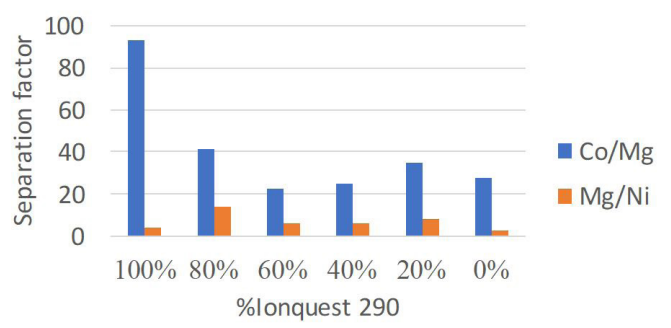

b)

Figure 4. Separation factor of cobalt/nickel (a), cobalt/magnesium and magnesium/nickel (b) of the experiments performed. 
Table 3. Concentration of nickel, cobalt and magnesium $(\mathrm{g} / \mathrm{L})$ on aqueous phase of the experiments performed

\begin{tabular}{ccccc}
\hline Experiment & $\begin{array}{c}\text { \%lonquest } \\
\mathbf{2 9 0}\end{array}$ & $\mathbf{N i}$ & $\mathbf{C o}$ & $\mathbf{M g}$ \\
\hline $\mathrm{I}$ & $100 \%$ & 74.9 & 0.03 & 1.5 \\
2 & $80 \%$ & 78.9 & 0.02 & 0.7 \\
3 & $60 \%$ & 83.9 & 0.1 & 1.4 \\
4 & $40 \%$ & 73.7 & 0.06 & 1.1 \\
5 & $20 \%$ & 77.4 & 0.04 & 1.0 \\
6 & $0 \%$ & 78.2 & 0.2 & 2.1 \\
\hline
\end{tabular}

higher using $80 \%$ of lonquest 290 (582.5), and lower using 100\% of Cyanex 272 (66.3). Cobalt/magnesium ratio was higher using $100 \%$ of lonquest 290 and lower using $60 \%$ of lonquest 290-92.9 and 22.7, respectively. Nickel/magnesium ratio was higher using $80 \%$ of lonquest 290 (14.0) and lower using $100 \%$ of Cyanex 272 (2.4).

By these results, cobalt separation from nickel-rich solution is higher using $80 \%$ of lonquest 290 and $20 \%$ of Cyanex 272. However, nickel losses were lower using $60 \%$ of lonquest $290-4.6 \%$. Table 3 shows the concentration of nickel, cobalt and magnesium on aqueous phase after the extraction. The lower concentration of cobalt was using $80 \%$ of lonquest $290(0.02 \mathrm{~g} / \mathrm{L})$. Nickel concentration was higher after solvent extraction experiments performed using $60 \%$ of lonquest $290-83.9 \mathrm{~g} / \mathrm{L}$.

Botelho et al. [25] studied the separation of cobalt from nickel-rich solution using Cyanex 272. The concentration of nickel and cobalt was lower than present in Table I - $13.2 \mathrm{~g} / \mathrm{L}$ and $0.17 \mathrm{~g} / \mathrm{L}$, respectively. The separation of cobalt was $99.45 \%$ at $65^{\circ} \mathrm{C}$ and $\mathrm{pH} 5.2$, and there were no losses of nickel [25]. For this reason, results show that with nickel and cobalt concentrated solution the use of synergism is useful.
Despite of these experiments, normally leach solution from nickel laterite ores has the present of iron, in which must be evaluated [3]. As Aliprandini [23] showed, iron can be removed using solvent extraction; however, losses of cobalt occurs. In solution studied by Aliprandini [23], iron removal by precipitation causes the co-precipitation of copper and cobalt, due to the high concentration of iron $(18.7 \mathrm{~g} / \mathrm{L})$. Botelho et al. [25] was able to remove iron by precipitation due to the low concentration of it in solution $(0.6 \mathrm{~g} / \mathrm{L})$.

Shi et al. [15] studied the synergism to recover vanadium using DEHPA and PC88A as organic extracts. Results showed that the maximum vanadium recovery was using $80 \%$ of DEHPA and $20 \%$ of PC 88 A, where it was possible $99.1 \%$ of extraction. By results obtained in this work, and also results showed from the literature, it is possible seen that synergism in solvent extraction have been explored for high efficiency on metals extraction.

\section{CONCLUSION}

A synthetic solution was prepared to simulate the real laterite nickel leachate from high-pressure acid leaching (HPAL). lonquest 290 and Cyanex 272 was used as organic extracts in kerosene. Results indicated that the highest cobalt extraction was using $80 \%$ of lonquest and $20 \%$ of Cyanex 272. However, nickel losses were lower using $60 \%$ of lonquest 290. Future studies should be focus on high metals separation for no nickel losses.

\section{Acknowledgements}

To the University of São Paulo, Capes and CNPq to support this project.

\section{REFERENCES}

I Mudd GM. Nickel sulfide versus laterite: the hard sustainability challenge remains. In: Canadian Metallurgical Society. Proceedings of the 48th Conference of Metallurgists; 2009; Sudbury, ON. USA: Canadian Metallurgical Society; 2009. p. I-I0.

2 Mudd GM. Global trends and environmental issues in nickel mining: sulfides versus laterites. Ore Geology Reviews. 2010;38:9-26. http://dx.doi.org//0.1016/j.oregeorev.2010.05.003.

3 Botelho Junior AB, Dreisinger DB, Espinosa DCR. A review of nickel, copper, and cobalt recovery by chelating ion exchange resins from mining processes and mining tailings. Mining, Metallurgy \& Exploration. 2018;36:199-213. http://dx.doi.org/10.1007/s4246I-018-0016-8.

4 Oxley A, Barcza N. Hydro-pyro integration in the processing of nickel laterites. Minerals Engineering. 2013;54:2-I3. http://dx.doi.org/10.1016/j.mineng.2013.02.012.

5 Crundwell FK, Moats MS, Ramachandran V, Robinson TG, Davenport WG. Extractive metallurgy of nickel, cobalt and platinum-group metals. Oxford: Elsevier; 20II.

6 Jiménez Correa MM, Aliprandini P, Tenório JAS, Espinosa DCR. Precipitation of metals from liquor obtained in nickel mining. In: Kirchain RE, Blanpain B, Meskers C, Olivetti E, Apelian D, Howarter J, et al. editors. REWAS 2016. Vol. I, Cham: Springer International Publishing; 2016, p. 333-338. http://dx.doi.org/10.1007/978-3-319-48768-7_52. 
7 Anes IA, Botelho Junior AB, Rosario C, Espinosa D, Tenório J. Selective recovery of copper from nickel laterite leach solution. In: Proceedings of the International Seminar on Process Hydrometallurgy; 20 I8; Santiago. Santiago: GECAMIN; 2018 . p. I-8.

8 Botelho Junior AB, Anes IA, Carvalho MA, Espinosa DCR, Tenório JAS. Recovery of Copper from nickel laterite leach waste by chemical reduction using sodium dithionite. Arizona: The Minerals, Metals \& Materials Society; 2018. p. 429-434. http://dx.doi.org//0.1007/978-3-319-72362-4_38.

9 Todd DB. Solvent extraction. In: Vogel HC, Todaro CM, editors. Fermentation and biochemical engineering handbook. 3rd ed. USA: Elsevier Inc.; 20I4. p. 225-238. http://dx.doi.org/I0.10 I6/B978-I-4557-2553-3.000I2-X.

10 Kislik VS. Final remarks on the competitive complexation/solvation theory of solvent extraction and its application. In: Kislik VS. Solvent extraction: classical and novel approaches. USA: Elsevier; 20I2. p. 433-436. http://dx.doi. org/I0.1016/B978-0-444-53778-2.1001 I-I.

I I Sole KC. Solvent extraction in the hydrometallurgical processing and purification of metals - process design and selected applications. In: Aguilar M, Cortina JL. Solvent extration and liquid membranes. USA: CRC Press; 2008. p. 63.

I 2 Kislik VS. Solvent extraction: classical and novel approaches. USA: Elsevier; 20 I4. http://dx.doi.org/10.1007/s I33980I4-0I73-7.2.

I 3 Mubarok MZ, Hanif LI. Cobalt and nickel separation in nitric acid solution by solvent extraction using Cyanex 272 and Versatic 10. Procedia Chemistry. 2016;19:743-750. http://dx.doi.org/10.1016/j.proche.2016.03.079.

14 Guimarães AS, Mansur MB. Selection of a synergistic solvent extraction system to remove calcium and magnesium from concentrated nickel sulfate solutions. Hydrometallurgy. 20 I8; I75:250-256. http://dx.doi.org/10.10 I6/j. hydromet.2017.12.001.

I5 Shi Q, Zhang Y, Huang J, Liu T, Liu H, Wang L. Synergistic solvent extraction of vanadium from leaching solution of stone coal using D2EHPA and PC88A. Separation and Purification Technology. 20 I7; I8I:I-7. http://dx.doi. org/10.1016/j.seppur.2017.03.010.

I6 Zagorodni AAA. Ion exchnange materials: properties and application. Vol. 33. Stockholm: Elsevier; 20I2. http:// dx.doi.org/10.1007/s |3398-0|4-0173-7.2.

17 Inamuddin ML. Ion exchange technology I. Vol. 10. New York: Springer; 20I2. http://dx.doi.org/I0.1524/ zpch.1957.10.5_6.350.

I8 Abrão A. Operações de troca iônica. São Paulo: Instituto de Pesquisas Energéticas e Nucleares - CNEN/SP; 20 I4.

19 Botelho Junior AB, Espinosa DCR, Dreisinger D, Tenório JAS. Effect of PH to recover $\mathrm{Cu}(\mathrm{II}), \mathrm{Ni}(\mathrm{II})$ and $\mathrm{Co}$ (II) from nickel laterite leach using chelating resins. Tecnologia em Metalurgia, Materiais e Mineração. 20 I9; I6:135- I40. http://dx.doi.org/10.4322/2176-I523.20191575.

20 Botelho Junior AB. Recuperação de níquel e cobalto a partir de lixiviado de níquel laterítico utilizando resinas quelantes e processo de pré-redução [dissertação]. São Paulo: Universidade de São Paulo; 2019.

2I Botelho Junior AB, Vicente ADA, Espinosa DCR, Tenório JAS. Effect of iron oxidation state for copper recovery from nickel laterite leach solution using chelating resin. Separation Science and Technology. 20 I 9;0: I - I I . http:// dx.doi.org/10.1080/01496395.2019.1574828.

22 Botelho Junior AB, Dreisinger DB, Espinosa DCR, Tenório JAS. Pre-reducing process kinetics to recover metals from nickel leach waste using chelating resins. International Journal of Chemical Engineering. 20 I8;20 I 8: I-7. http:// dx.doi.org/10.1155/2018/9161323.

23 Aliprandini P. O uso da extração por solventes para tratamento de licor de lixiviação de minério limonítico de níquel [dissertação]. São Paulo: Universidade de São Paulo; 2017.

24 Liu Y, Lee MS. Separation of cobalt and nickel from chloride leach solution of nickel laterite ore by solvent extraction. Geosystem Engineering. 2016;19:2 I4-22I. http://dx.doi.org/10.1080/I2269328.2016.I I6409I.

25 Botelho Junior AB, Espinosa DCR, Dreisinger D, Tenório JAS. Recovery of nickel and cobalt from nickel laterite leach solution using chelating resins and pre-reducing process. The Canadian Journal of Chemical Engineering. 2018;97(5). http://dx.doi.org/10.1002/cjce.23359.

26 CYTEC. CYANEX 272 extractant 2008. [cited 2018 Jan 17]. Available at: http://www.cytec.com/sites/default/files/ datasheets/CYANEX 272 Brochure.pdf

27 Rydberg J, Cox M, Musikas C, Choppin GR. Solvent extraction principles and practice. Boca Raton: CRC Press; 2004. http://dx.doi.org/10.1201/9780203021460. 
28 Guimarães AS, Silva PS, Mansur MB. Purification of nickel from multicomponent aqueous sulfuric solutions by synergistic solvent extraction using Cyanex 272 and Versatic 10. Hydrometallurgy. 2014;150: 173-177. http://dx.doi. org/10.1016/j.hydromet.2014.10.005.

29 Oliveira GFR. Estudo de extração por solvente para separação de cobalto do níquel utilizando Cyanex 272 e lonquest 290 [trabalho de conclusão de curso]. São Paulo: Universidade de São Paulo; 2017.

30 Santanilla AJM. Estudo dos complexos organometálicos formados na etapa de extração de níquel e cobalto, através do uso de extratantes ácidos [tese]. São Paulo: Universidade de São Paulo; 2017.

3I Gupta CK. Chemical metallurgy: principles and practice. Mumbai: Elsevier; 2003.

Received: II Dec. 2018

Accepted: II May 2019 